\title{
Structure and Hibernation-associated Expression of the Transient Receptor Potential Vanilloid 4 Channel (TRPV4) mRNA in the Japanese Grass Lizard (Takydromus tachydromoides)
}

\author{
Kazuya Nagai ${ }^{1}$, Yasushi Saitoh ${ }^{1}$, Shigeru Saito ${ }^{2 \dagger}$, and Ken-ichi Tsutsumi ${ }^{1 *}$ \\ ${ }^{1}$ United Graduate School of Agricultural Sciences, Iwate University, Morioka, Iwate 020-8550, Japan \\ ${ }^{2}$ Faculty of Engineering, Iwate University, Morioka, Iwate 020-8550, Japan
}

\begin{abstract}
Animals possess systems for sensing environmental temperature using temperature-sensitive ion channels called transient receptor potential channels (TRPs). Various TRPs have been identified and characterized in mammals. However, those of ectotherms, such as reptiles, are less well studied. Here, we identify the V subfamily of TRP (TRPV) in two reptile species: Japanese grass lizard (Takydromus tachydromoides) and Japanese four-lined ratsnake (Elaphe quadrivirgata). Phylogenetic analysis of TRPVs indicated that ectothermic reptilian TRPVs are more similar to those of endothermic chicken and mammals, than to other ectotherms, such as frog and fish. Expression analysis of TRPV4 mRNA in the lizard showed that its expression in tissues and organs is specifically controlled in cold environments and hibernation. The mRNA was ubiquitously expressed in seven tissues/organs examined. Both cold-treatment and hibernation lowered TRPV4 expression, but in a tissue/organ-specific manner. Cold-treatment reduced TRPV4 expression in tongue and muscle, while in hibernation it was reduced more widely in brain, tongue, heart, lung, and muscle. Interestingly, however, levels of TRPV4 mRNA in the skin remained unaffected after entering hibernation and cold-treatment, implying that TRPV4 in the skin may act as an environmental temperature sensor throughout the reptilian life cycle, including hibernation. This is the first report, to our knowledge, to describe reptilian TRPV4 in relation to hibernation.
\end{abstract}

Key words: hibernation, cold response, TRP, temperature sensing, reptile

\section{INTRODUCTION}

Animals experience various environmental conditions such as changing temperature, requiring adaptation at both behavioral and physiological levels. One such mechanism involves temperature-sensitive channels called transient receptor potential (TRP) ion channels. Various TRPs have been identified in animals, and these are categorized into several subfamilies, including TRPV (vanilloid), TRPM (melastatin), and TRPA (ankyrin) (Patapoutian et al., 2003; Vriens et al., 2004; Voets et al., 2005). Thermo-sensitive TRPs (called thermo TRPs) are expressed in the sensory organs and peripheral nervous system, and are involved in sensing temperature, as well as light, atmospheric pressure, and several chemical stimuli (Voets et al., 2005; Damann et al., 2008).

Although animal TRPs have been studied extensively, information concerning to reptilian TRPs is scarce. Reptiles are ectothermic animals, which cannot autonomously regulate their body temperature. Instead, they regulate it by

\footnotetext{
* Corresponding author. Tel. : :+81-19-621-6242;

Fax : +81-19-621-6242;

E-mail: kentsu@iwate-u.ac.jp

$\dagger$ Present address: Division of Cell Signaling, Okazaki Institute for Integrative Bioscience (National Institute for Physiological Sciences), National Institutes of Natural Sciences, Okazaki, Aichi, Japan

doi:10.2108/zsj.29.185
}

using environmental energy and behavioral adaptations, such as basking (Seebacher, 1999). Therefore, the physiological roles of reptilian TRPs differ from those of endothermic animals, though ectothermic reptiles are reported to be closer to endothermic avians than to ectothermic amphibians (Iwabe et al., 2005). In these respects, reptilian thermo TRPs are particularly interesting from the evolutionary perspective. In addition, temperature sensing of reptilian TRPs might differ from other animals. For example, mammalian TRPA1 senses low temperature, whereas the snake orthologs senses higher temperature (Gracheva et al., 2010). Moreover, since reptiles are hibernating animals, they might be a suitable model to investigate how hibernation regulates TRPs, or vice versa.

Our study aimed to know the function of TRPs in body temperature control and in hibernation in ectothermic reptiles. For this purpose, we focused on TRPV4, as it is a nonselective cation channel involved in sensing temperature, osmotic and chemical stimuli, and in control of skin temperature and barrier formation (Damann et al., 2008; Sokabe and Tominaga, 2010), all of which might concern to the events in hibernation. As an initial step, we report cDNA sequences encoding lizard and snake TRPV4 orthologs, and show phylogenetic relationship of TRPs in animals. In addition, we demonstrate, for the first time, that expression of TRPV4 is controlled in a tissue/organ-specific manner under hibernation status. 


\section{MATERIALS AND METHODS}

Animals

The Japanese grass lizard (Takydromus tachydromoides), the Japanese four-lined snake (Elaphe quadrivirgata), and red-eared slider (Trachemys scripta elegans) used in this study were captured from the fields in Iwate Prefecture, Japan. The specimens were bred at $25^{\circ} \mathrm{C}$ in the laboratory.

\section{Cold-treatment and induction of hibernation of lizards}

Cold-treatment and induction of hibernation of lizards were carried out in a cage with soil and fallen leaves therein. Cold-treatment was carried out using wild lizards captured in July (early summer). The lizards were placed at $8^{\circ} \mathrm{C}$ for $48 \mathrm{~h}$ in the dark without feeding, except water. For induction of hibernation, lizards were fed ad libitum at room temperature in the laboratory until prehibernal period (November). Then, the animals were kept at $8^{\circ} \mathrm{C}$ in the dark, as for the cold-treatment described above. With this treatment, hibernation started at late November and lasted for about four months. Hibernation was characterized by a state of inactivity, no interactions among individuals, and lowered breathing, as described by Grenot et al. (2000) and Michaelidis et al. (2002).

RNA preparation, cDNA synthesis, and expression analysis

Total RNA was extracted from various tissues of the bred specimens, using the acid guanidinium thiocyanate-phenol-chloroform method (Chomczynski and Sacchi, 1987), and treated with DNase to eliminate contaminated genomic DNA. To generate first-strand cDNA, $1 \mu \mathrm{g}$ total RNA was reverse transcribed with oligo (dT) 15 primer using ReverTra Ace reverse transcriptase (Toyobo, Osaka, Japan). The cDNA was amplified by PCR with the gene-specific primer sets listed in Table 1 (their positions are shown in Fig. 1). These primers were designed from highly conserved regions of the cognate genes so far reported for animals. The forward and reverse primers sandwiched the intron region, to distinguish the products from genomic DNA. Thermal cycling was conducted as follows: denaturing at $94^{\circ} \mathrm{C}$ for $5 \mathrm{~min}$ followed by 35 cycles of $95^{\circ} \mathrm{C}$ for $10 \mathrm{sec}, 60^{\circ} \mathrm{C}$ (TRPV4 and CTNNB1, primer set 1 and 3 , respectively) or $57^{\circ} \mathrm{C}$ (WAC, primer set 2) for $30 \mathrm{sec}$, and $72^{\circ} \mathrm{C}$ for $30 \mathrm{sec}$. The products were separated by $2 \%$ agarose gel electrophoresis and visualized by ethidium bromide staining. WAC (WW domain containing adaptor with coiled-coil; $X u$ and Arnaout, 2002) and CTNNB1 (catenin beta 1; Kraus et al., 1994) were used as control mRNAs for expression analysis.

\section{3'- and 5'RACE}

Full-length CDNA was obtained by 3 '- and 5' RACE as follows. The 3'-terminal end of TRPV4 CDNA was obtained by PCR using GeneRacer 3' adapter-specific primer (5'-GCTGTCAACGATACGCTACGTAACG-3', Invitrogen, CA, USA) and the gene-specific primers (5'-AGATTGAGAACCGCCACGAGATGCT-3' for lizard, and 5'-

Table 1. Primer sets used in this study.

\begin{tabular}{|c|c|c|c|c|}
\hline $\begin{array}{l}\text { Primer } \\
\text { set }\end{array}$ & Target & Primera) & Nucleotide sequence $\left.\left(5^{\prime} \text { to } 3^{\prime}\right)^{\mathrm{b}}\right)$ & $\begin{array}{l}\text { Product size } \\
\quad(\mathrm{bp})\end{array}$ \\
\hline \multirow[t]{2}{*}{1} & TRPV4 & $\mathrm{V} 4 \mathrm{~F}$ & CTTCTTCCAGCCCAAGGATG & 299 \\
\hline & & V4R & GTCTTGGCAGCCATCATGAG & \\
\hline \multirow[t]{2}{*}{2} & $W A C^{c)}$ & wacF & TGCATCACCTCTCTTCTGTAAT & 271 \\
\hline & & wacR & CTGCGGATGATTGGTCTGA & \\
\hline 3 & CTNNB1 ${ }^{d)}$ & $\begin{array}{l}\operatorname{ctn} F \\
\operatorname{ctn} R\end{array}$ & $\begin{array}{l}\text { GAGTTGGATATGGCCATGGA } \\
\text { GATGGRATYTGCATKCCYTCATC }\end{array}$ & 279 \\
\hline
\end{tabular}

a) $F$ : forward primer, $R$ : reverse primer

b) $D: G$ or $A$ or $T, Y: C$ or $T, V: G$ or $A$ or $C, W: A$ or $T, K: G$ or $T, R: A$ or $G$.

c) WAC: WW domain containing adaptor with coiled-coil (Xu et al., 2002).

d) CTNNB1: catenin (cadherin-associated protein) beta 1 (Kraus et al., 1994).
GGACAGCAAGACCTTCAGCACCTTC-3' for snake). The 5'-end sequences were determined as follows; the GeneRacer RNA adapter (50 pmol, Invitrogen, CA, USA) was ligated to total RNA $(10 \mu \mathrm{g})$ with T4 RNA ligase (New England Biolabs), followed by reverse transcription using ReverTra Ace reverse transcriptase (TOYOBO) and random primers. Amplification was done using GeneRacer 5' adapter-specific primer (Invitrogen, CA, USA) and the gene-specific primers (lizard: 5'-GGCAGCTCACCGAAGTAGAAGTAG-3', snake: 5'-CATCCTTGGGCTGGAAGAA-3').

\section{Sequencing and phylogenetic analysis}

Nucleotide sequencing was carried out using an 8-capillary 3500 Genetic Analyzer (Applied Biosystems). Multiple sequence alignment was performed using CLUSTAL $W$ (Thompson et al., 1994). Phylogenetic relationships among the chosen sequences were constructed by minimum-evolution methods (ME; Rzhetsky and Nei, 1987), using MEGA 4 software (Tamura et al., 2007). Nucleotide sequence data are available in the DDBJ/EMBL/ GenBank Database under the accession numbers $A B 666086$, AB666087, AB666088, AB666089, and AB666090.

\section{RESULTS AND DISCUSSION}

Isolation of reptilian TRPV4 CDNAs and deduced amino acid sequences

As an initial step to investigate structure and function of TRPVs in reptiles, we isolated TRPV4 cDNAs from the Japanese grass lizard (Takydromus tachydromoides) and the Japanese four-lined snake (Elaphe quadrivirgata), as described in Materials and Methods. Both the deduced TRPV4 proteins comprised 868 amino acids. Alignment of these TRPV4s with those of other tetrapods revealed high homology (Fig. 1). Homology between lizard and snake, chicken, human, mouse, rat and frog were $96 \%, 85 \%, 84 \%$, $84 \%, 83 \%$ and $79 \%$, respectively. Lizard and snake TRPV4 showed highest similarity to the chicken TRPV4, but differed in that the latter had deletions of 5 and 7 amino acids at $\mathrm{N}$ terminal region and deletion of five amino acids near $\mathrm{C}$ terminus (Fig. 1). Those reptilian TRPV4s had all the structural and functional domains conserved in other TRPs, such as ankyrin repeat (ANK), proline-rich domain (PRD), transmembrane (TM), pore region or pore loop (PL), TRP domains, and calmodulin binding domains (CaMBD) (Venkatachalam and Montell, 2007; Phelps et al., 2008; Everaerts et al., 2010).

\section{Phylogenetic analysis}

To better understand genetic relationships of TRPVs of reptiles and of other animals, phylogenetic tree was constructed by ME methods using amino acid sequences of TRPVs (Fig. 2). As shown in the figure, TRPV subfamilies TRPV1, TRPV2, TRPV3, and TRPV4 formed independent clusters. Each subfamily clustered into a clade formed with different animals employed here. TRPV5 and TRPV6 are more divergent; they formed clades that are distant from other TRPVs.

TRPV4 from lizard and snake grouped together and clustered with birds (chicken and turkey), but located as a different clade from frog and fish. Similar tree can be constructed using partial amino acid sequences including those of TRPV2 and TRPV3 from other reptile (turtle, Trachemys scripta elegans) (DDBJ/EMBL/GenBank accession nos. AB666086 and AB666087, data not shown). Thus, for all TRPVs analyzed here, reptiles (lizard, snake, and turtle) 
lizard TRPV4 snake TRPV4 human TRPV4 mouse TRPV chicken TRPV frog TRPVAa

lizard TRPV4 snake TRPV 4 human TRPV4 mouse TRPV chicken TRPV4 frog TRPV4a

lizard TRPV4 snake TRPV4 human TRPVA mouse TRPV4 chicken TRPV frog TRPV 4

lizard TRPV4 snake TRPV4 human $z$ TRPV 4 mouse TRPV4 chicken zTRP frog TRPV4a

lizard TRPV4 snake TRPV4 human TRPV4 mouse TRPV chicken TRPV frog TRPV $4 \mathrm{a}$

lizard TRPV4 snake TRPVA human TRPVA mouse TRPV4 chicken TRPV frog TRPV4a

lizard TRPV4 snake TRPV4 human TRPV mouse TRPVA chicken TRPV4 frog TRPV4a

lizard TRPV4 snake TRPV4 human TRPV mouse TRPV 4 chicken TRPV4 frog TRPV4a

lizard TRPV4 snake TRPV4 human TRPV4 mouse TRPVA chicken TRPV4 frog TRPV4a
MANLEDAAHASPSESTESPSEE-ISPQNDSFPLSSLANLEENEDG--APAAEAARTPPGAGDGKQNLRMKFHGAFRKGVPNPMDLLESTIYESSVVSGPK 97 MANLEDAAHASPSESTESPSEE-ISPONDSFPLSSLANLFENEDG--APAAEAARTPPGAGDGKONLRMKFHGAFRKGVPNPMDLLESTIYESSVVPGPK 97 MADSSEGPRAGPGEVAELPGDESGTPGGEAFPLSSLANLFEGEDGSLSPSPADASRPAGPGDGRPNLRMKFOGAFRKGVPNPIDLLESTLYESSVVPGPK 100 MADPGDGPRAAPGEVAEPPGDESGTSGGEAFPLSSLANLFEGEEGSSSLSPVDASRPAGPGDGRPNLRMKFQGAERKGVPNPIDLLESTRYESSVVPGPK 100 MADPED-----PRDAGDVLGDD------SEPLSSLANLFEVEDT--PSPAEPSRGPPGAGDGKQNLRMKFHGAERKGPPKPMELLESTIYESSVVPAPK 86 MADPSHLLKHNASVDIDDSQGDDGSNHNDSFPLSSLANLFENEES--SAPNEGVRSPQVPGDNKQNLRIRFQGPERKGISNPMDLLESTIYESS---APK 95

KAPMDSLFDYGTYRHHPSDNKRRRKK-ALEKKPPSTKGRAPHPPPI LKVFNRPILFDIVSRGSTADLDGLLPELLTHKKRLTDEEFREFSTGKTCLPKAL 196 KAPMDSLFDYGTYRHHPS DNKRRRKK-ALEKKPPSTKGPAPHPPPI LKVENRPIIFDIVSRGSTADLDGLLPFLLTHKKRLTDEEFREPSTGKTCLPKAL 196 KAPMDSLFDYGTYRHHSS DNKRWRKK-I IEKQPQS PKAPAPORPPI LKVFNRPIIEDIVSRGSTADLDGLLPFLLTHKKRLTDEEFREPSTGKTCLPKAL 199 KAPMDSIFDYGTYRHHPSDNKRWRRK-VVEKQPOSPKAPAPQPPPI LKVFNRPILFDIVSRGSTADLDGLISFLLTHKKRLTDEEEREPSTGKTCLPKAL 199 KAPMDSLEDYGTYRQHPSENKRWRRR-VVEKPVAGTKGPAPNPPPVLKVFNRPILFDIVSRGSPDGLEGLLSFLLTHKKRLTDEEFREPSTGKTCLPKAL 185 KAPMDSLFGYETYHHHPTENRRKRKK I LLEKENLNSQAPSPDPPPVI KMFNRHMLFDIVSRGSTAELEGELPFLLAQKKRLTDEEEREASTGKTCLTKAL 195 ARD 1 ARD 2

LNLNNGKNDTIPFLIDIAEKTGSTREFINSPFRDVYYRGOTALHIAIERRCKHYVELLVEKGADVHAOARGRFFQPRDEGGYFYFGELPLSLAACTNQPH 296 LNLNNGKNDT IPFLIDIAEKTGSTREFINSPFRDVYYRGQTALHIAIERRCKHYVELLVEKGADVHAQARGRFFQPKDEGGYFYFGELPLSLAACTNQPH 296 LNLSNGRNDTIPVLLDIAERTGNMREF INSPFRDIYYRGQTALHIAIERRCKHYVELLVAQGADVHAQARGRFFQPKDEGGYFYFGELPLSLAACTNQPH 299 LNLSNGRNDTIPVLLDIAERTGNMREF INSPFRDIYYRGQTSLHIAIERRCKHYVELLVAOGADVHAOARGRFEOPKDEGGYFYFGELPLSLAACTNQPH 299 INTSAGRND MNLNGGKNDTIPMLIDIAEKTGNLREF INSPFRDVYYRGQTALHIAIERRCKHYVELLVEKGADVHAQARGRFEQPKDEGGYFYFGELPLSLAACTNQPD 295 ARD $3 \quad \stackrel{\text { Primer V4F }}{\text { ARD } 4}$

IVHYLTENAHKQADLRRQDSRGNTVLHALVAIADNTRENTKFVTKMYDLLL IKCAKLEPDTNLEALLNNDGLSPLMMAAKTGKIGAFOHI IRRE I KDEDA 396 IVQYLTENAHKOADLRRQDSRGNTVLHAIVAIADNTRENTKFVTKMYDLLLIKCAKLEPDTNLEALLNNDGLSPLMMAAKTGKIGMFQHIIRREVKDEEA 396 IVNYLTENPHKKADMRRODSRGNTVLHALVAIADNTRENTKFVTKMYDLLLLKCARLFPDSNLEAVLNNDGLSPLMMAAKTGKIGVFOHIIRREVTDEDT 399 IVNYLTENPHKKADMRRODSRGNTVLHALVAIADNTRENTKFVTKMYDLLLIKCSRLFPDSNLETVLNNDGLSPLMMAARTGKIGVFOHIIRREVTDEDT 399 4 IVHYLTENGHKQADLRRQDSRGNTVLHALVAIADNTRENTKFVTKMYDLLLI KCAKLEPDTNLEALLNNDGLSPLMMAAKTGKIGI FQHI IRRE I ADEDV 385 IVHYLTENAHKKADIRRQDSRGNTVLHALVAIADNTRENTKEVTKVYDLLVIKCVKLYPDSSLEA I FNNDSMSPLMMAAKLGKIG I FOHI IRLE I KDEEA 395 ARD 5 Primer V4R ARD 6

RHLSRKEKDWAYGPVYSSLYDLSSLDTCGEEDSVLEI LVYNSKMENRHEMLAVEPINELLRDKWRKFGAVS FYISVVSYLCAMIIFTMVAYYRPLEGTPP 496 RHLSRKFRDWAYGPVYSSLYDLSSLDTCGEEVSVLEILVYNSKIENRHEMLAVEPTNELLRDKWRKFGAVSFYISVVSYLCAMVIFTLVAYYRPLEGTPP 496 RHLSRKFKDWAYGPVYSSLYDLSSLDTCGEEASVLEILVYNSKIENRHEMLAVEP INELLRDKWRKFGAVSFYINVVSYLCAMVIFTLTAYYQPLEGTPP 499 RHLSRKFKDWAYGPVYSSLYDLSSLDTCGEEVSVLEILVYNSKIENRHEMLAVEPINELLRDKWRKFGAVSFYINVVSYLCAMVIFTLTAYYQPLEGTPP 499 RHLSRKEKDWAYGPVYSSLYDLSSLDTCGEEVSVLEILVYNSKIENRHEMLAVEPINELLRDKWRKFGAVSFYISVVSYLCAMIIITTLIAYYRPMEGPPP 485 RHLSRKERDWAYGPVYSSLYDLSMLDTCGEEVSVLEILVYNSKVENRHEMLAVEPINELLRDKWQKFGAVSFYISVVSYLIAMIIFTLIAYYRPMDGTPP 495 TM 1

YPYTTTTDYLRLAGEIVTLFTGVLFFFTNIKDLEMKKCPGVNSFFIDGSFQLLYFIYSVLVLVAAALYLTGIEAYLAVMVFALVLGWMNALYFTRGLKLT 596 YPYTTTPDY LCLAGE IVTLFTGVLFF FTN IKDLFMKKCPGVNSFF I DGSFQLIYFIYSVLVLVAAALYLAGIEAYLAVMVFALVLGWMNALYFTRGLKLT 596 YPYRTTVDYLRLAGEVITLFTGVLFFFTNIKDLFMKKCPGVNSIE I DGSFOILYFIYSVLVIVSAALYLAGIEAYLAVMVFALVLGWMNALYFTRGLKLT 599 YPYRTTVDYLRLAGEVITLFTGVLFFFTSIKDLFTKKCPGVNSLFVDGSFQLLYFIYSVLVVVSAALYLAGIEAYLAVMVFALVLGWMNALYFTRGLKLT 599 YPYTTT IDY LRLAGE I ITLLTGI LFFFSN I KDLFMKKCPGVNSFFI DGSFOLLYFIYSVLVIVTAGLYLGGVEAYLAVMVFALVLGWMNALYFTRGLKLT 585 YPYRTTMDYMRLAGE IVTLLTGVVFFITN IKDLEMKKC PGVNSLF I DGSFQLLYFIYSVLVI I TAVLYLVGIESYLAVMVEALVLGWMNALYFTRGLKLT 595 TM 2

TM 3

TM 4

GTYSIMIQKILFEDLFRFLLVYVLFMIGYASALVSLLNPCPSSEACSEERSNCTAPAYPSCRDSKTFSNFLLDLFKLTIGMGDLEMIESAKYFGVFVILL 696 GTYSIMIQKILFKDLFRFLIVYVLFMIGYASALVSLLNPCPSAESCRGDHSNCTAPAYPSCRDSKTFSTFLIDLFKLTIGMGDLEMIENAKYPGVFVILI 696 GTYSIMIOK I LFKDLFRFLLVYLLFMIGYASALVSLLNPCANMKVCNEDQTNCTVPTYPSCRDSETFSTFLLDLFKLTIGMGDLEMLSSTKYFVVFI ILL 699 GTYSIMIQKILFKDLFRFLLVYLLFMIGYASALVTLLNPCTNMKVCDEDQSNCTVPTYPACRDSETFSAFLLDLFKLTIGMGDLEMLSSAKYPVVFILLI 699 GTYSIMIQK ILFKDLFRFLLVYLLFMIGYASALVSLLNPCP SSESCSEDHSNCTLPTYPSCRDSQTFSTFLIDLFKLTIGMGDLEMLESAKYPGVFI I LI 685 GTYSIMLQKILFKDLFRFLLVYLLFMIGYASALVSLLNPCTSQESCIETSSNCTVPEYPSCRDSSTFSKFLLDLFKLTIGMGDLEMINSAKYPAVFI ILL 695 TM 5 PL

VTYIILTFVLILNML IALMGETVGOVSKESKOIWKLOWATT I LDIERFFPVFVRKAFRSGEMVTVGKSLDGTPDRRWCFRVDEVNWFHWNONLGI INEDP 796 VTY I ILTEVLILNML I ALMGETVGQVSKE SKK IWKLOWATTI LDIERSFPVFVRRAFRSGEMVTVGKSLDGAPDRRWCFRVDEVNWSHWNONLGI ISEDP 796 VTYIILTEVLLINML IALMGETVGQVSKE SKH IWKLQWATTILDIERSF PVFLRKAFRSGEMVTVGKSSDGTPDRRWCFRVNEVNWSHWNQNLGI INEDP 799 VTYIILTFVLLLNML I ALMGETVGQVSKESKH IWKLQWATTILDIERSF PVF LRKAFRSGEMVTVGKSSDGTPDRRWCERVDEVNWSHWNQNLGI INEDP 799 VTYIILTFVLLLNML IALMGETVGQVSKESKH IWKLQWATT I LDIERSFPLFLRRAFRSGEMVTVGKGTDGTPDRRWCFRVDEVNWSHWNQNLGI ISEDP 785 VTYIILTEVLLLNML IALMGETVGQVSKE SKQIWKLQWATTI LDIERSF PVCMRKAFRSGEMVTVGKNLDGT PDRRWCFRVDEVNWSHWNQNLGI INEDP 795 TM 6 TRP

GKNDTYQYYGESHTVGRLRRDRWSTVVPRVVELNKN-LQPDEVVVPLDSMRSPAANEHKPSYPQSWRKEDSHI* 868 GKNDTYQYYGFSHTVGRLRRDRWSTVVPRVVELNKN-SQPDEVVVPLDSMCSAGANAHKPSYPHSWRKEDAQI* 868 GKNETYQYYGFSHTVGRLRRDRWSSVVPRVVELNKN-SNPDEVVVPLDSMGNPRCDGHQQGYPRKWRTDDAPL * 871 GKSEI YQYYGESHTVGRLRRDRWSSVVPRVVELNKN-SSADEVVVPL DNLGNPNCDGHOOGYAPKWRTDDAPL * 871 GKSDTYQYYGFSHTVGRLRRDRWSTVVPRVVELNKS-CPTEDVVVPLGTMGTAEARERRHG-----OTPSSPL * 852 GRNDGYQYYGESQTVGRLRRDRWSVVVPRVVELNKAPQHSDDVVVPLGNIPQVQTYSQRQENAQNWKKDETHI* 868 CaMBD

Fig. 1. Comparison of amino acid sequences of TRPV4 from lizard and snake with those of other animals. Full-length amino acid sequences of TRPV4 from lizard and snake, which were deduced from CDNA, were aligned with those of human, mouse, chicken, and frog. PRD, TM, PL, TRP, ARD and CaMBD indicate proline-rich domain, transmembrane regions, pore region or pore loop, TRP domain, ankyrin-repeat domain and calmodulin binding domains, respectively (Phelps et al., 2008; Everaerts et al., 2010). Numbers shown on the right are amino acid positions for each sequence. Hyphens indicate deletions made for maximal matching. Positions and orientations that correspond to nucleotide sequences designed for PCR primers (V4F and V4R, see also Table 1 for nucleotide sequences) were indicated by arrows.

located close to chicken in the tree.

Reptiles, frog, and zebrafish are ectothermic animals. Interestingly, however, the tree in Fig. 2 showed that reptilian TRPV sequences are more closely related to endothermic chicken than to ectothermic frog and fish. Frog and zebrafish formed clades separate from reptiles, chicken and mammals.

Expression of TRPV4 mRNA is ubiquitous among tissues/organs but is altered during hibernation

Levels of TRPV mRNAs in the lizard tissues/organs were examined by RT-PCR using total RNA prepared from 


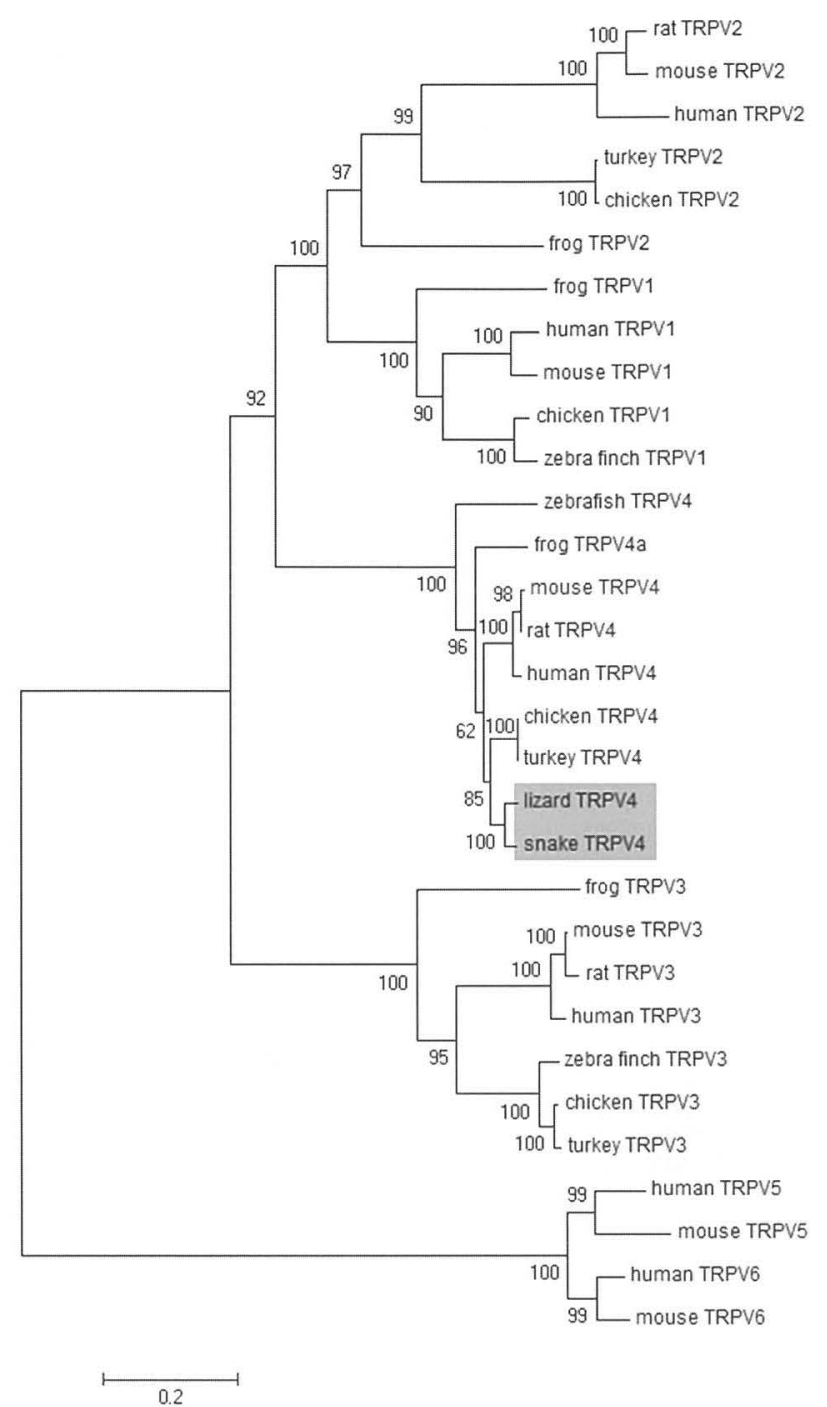

Fig. 2. Phylogenetic tree constructed with vertebrate TRPVs. The tree was constructed using amino acid sequences of TRPVs from various vertebrates, which contain conserved domains including the ankyrin repeat and transmembrane domains (656 residues, corresponding to position from 141 to 796 in lizard TRPV4). Each sequence was aligned for the same region, and used for the tree construction by ME method (Rzhetsky et al., 1992). Bootstrap values were calculated from 1,000 replicates and indicated at the branches (> 50\%). Genes that the amino acid sequences were determined in this study are shaded. Database accession numbers of the genes used for the tree construction are; human TRPV1: AJ277028, mouse TRPV1: AB180097, rat TRPV1: AF029310, chicken TRPV1: AY072909, zebra finch TRPV1: XP_002195940, frog TRPV1 pre: XM_002938256, human TRPV2: Af129112, mouse TRPV2: AB021665, rat TRPV2: AF129113, chicken TRPV2: XM_415848, turkey TRPV2 pre: ENSMGAT00000007327, zebra finch TRPV2: XP002195797, frog TRPV2 pre: ENSGALT00000012785, human TRPV3: AJ487035, mouse TRPV3: AF510316, rat TRPV3: AY325813, chicken TRPV3 pre: ENSGALT00000007425, turkey TRPV3 pre: ENSMGAT00000007547, zebra finch TRPV3: XP002195959, anole (green anole) TRPV3 pre: ENSACAT00000001754, frog TRPV3 pre: XM_002938252, human TRPV4: AF263523, mouse TRPV4: AF263521, rat TRPV4: AF263521, chicken TRPV4: AF261883, turkey TRPV4 pre: ENSMGAT00000007141, zebrafish TRPV4: DQ858167, frog TRPV4a pre: ENSXETT00000040300, human TRPV5: NM019841, mouse TRPV5: NM001007572, human TRPV6: NM018646, mouse TRPV6: NM022413. brain, tongue, heart, lung, liver, muscle and skin. The cognate mRNAs in the snake and turtle were also detected by RT-PCR using the primer set for lizard TRPV4 (Table 1). The primers for lizard worked for snake and turtle, as confirmed by sequencing the PCR products and by RT-PCR using unrelated templates (plant RNAs, Fig. 3B). For control experiments, WAC mRNA was analyzed in parallel. As shown in Fig. 3A, TRPV4 mRNA was ubiquitously expressed in all tissues/organs examined in the lizard, snake, and turtle, though it was less abundant in skeletal muscle in snake.

We next examined whether cold-treatment and hibernation alter expression of the TRPV4 mRNA in lizards. Cold treatment of the lizards was carried out at $8^{\circ} \mathrm{C}$ for $48 \mathrm{~h}$, and RNAs were extracted from various tissues/organs. In this experiment, two mRNAs (WAC and CTNNB1) were included as controls, in order to firmly show equal recovery of RNA and to show their constant expression. Interestingly, cold treatment altered the mRNA expression in a tissue/organspecific manner. Expression of TRPV4 mRNA was reduced in tongue and muscle (Fig. 4B), as compared to control lizard (Fig. 4A), while the control mRNAs (WAC and CTNNB1) remained almost unaffected in all tissues/organs.

Hibernation also affected expression of TRPV4 mRNA. In the lizards at two months after entering hibernation (late January), the expression was reduced in all tissues/organs, except for skin and, with less apparent, liver (Fig. 4C). At four months after entering hibernation (just prior to emergence from hibernation), expression of TRPV4 mRNA was restored in the heart and brain (Fig. 4D). These results were
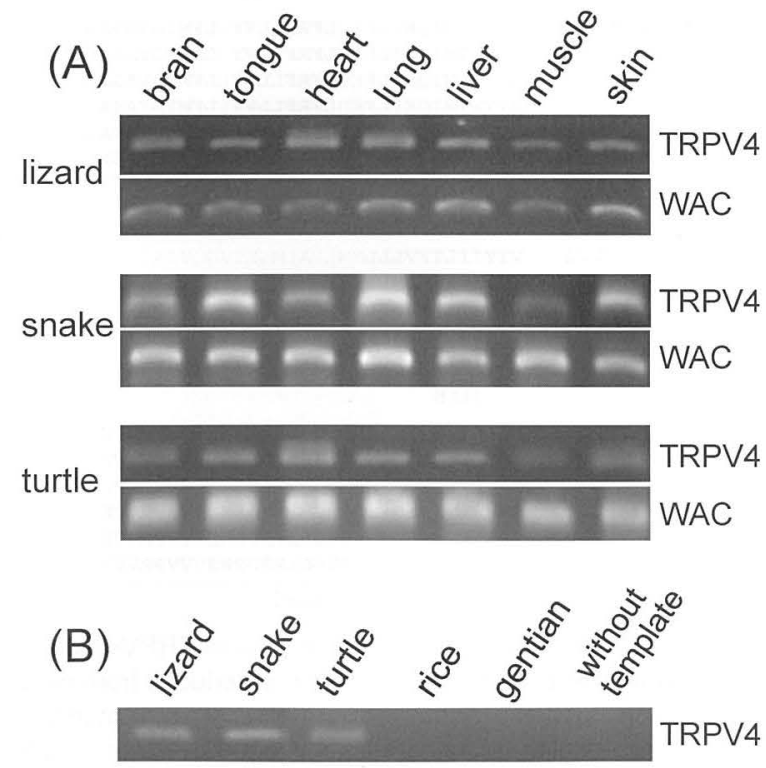

Fig. 3. Expression of TRPV4 mRNA in different tissues/organs in lizard, snake, and turtle. (A) Expression of TRPV4 in lizard, snake and turtle. Total RNAs from each tissue/organ was subjected to RTPCR using TRPV4 -specific primers and the products were run on agarose gel (see Materials and Methods). Control experiments were done using primers for WAC mRNA. (B) Specificity of the TRPV4 primers. Total RNAs from rice (Oryza sativa) and gentian (Gentiana triflora) plants were used as templates for RT-PCR as in (A). Rice and gentian RNAs were used as negative controls, showing specificity of the primer. 


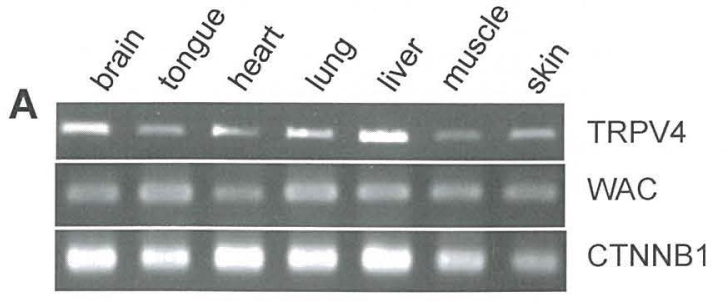

B
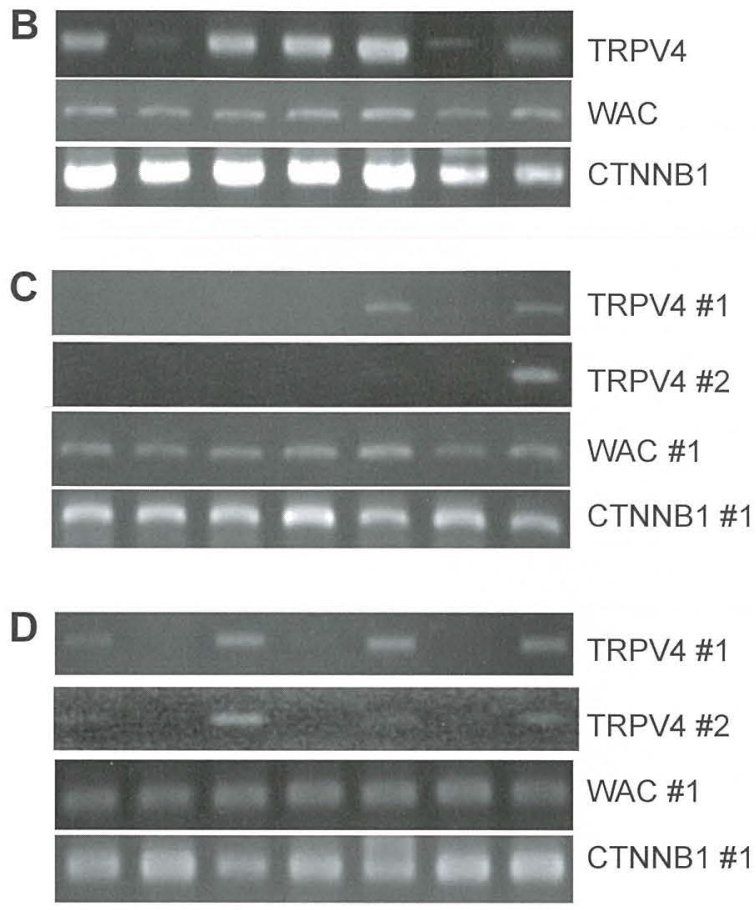

Fig. 4. Cold- and hibernation-related alternation of TRPV4 expression in different tissues/organs in the lizard. Expression of the mRNA was analyzed as in Fig. 3. (A) non-hybernating (control). (B) exposed at $8^{\circ} \mathrm{C}$ for $48 \mathrm{~h}$. (C) mid-hibernation (at the stage about 2 months after entering hibernation). (D) late hibernation (at about 4 months after entering hibernation). TRPV4 \#1 and \#2 in (C) and (D) indicate results from different animals under the same condition. WAC and CTNNB1 mRNAs were used as controls.

reproducible for different individuals. Thus, expression of TRPV4 mRNA in the skin remains unchanged after entering hibernation, while the expression significantly decreased in other tissues/organs. The TRPV4 levels in the heart and brain restore later during the course of hibernation.

To date, the full amino acid sequence of reptilian TRPVs have been unknown; only partial sequences have been reported for TRPV1 and TRPM8 from lizard and crocodile (Seebacher and Murray, 2007). In this study, we determined, for the first time, complete amino acid sequences of TRPV4 in the lizard and snake. Amino acid sequence of the reptilian TRPV4 shares important structural and functional domains with those of other tetrapods. We also determined partial amino acid sequences of TRPV2 and TRPV3 from turtle. Our data, together with other reports (Saito et al., 2011), show the occurrence of at least six thermo TRP repertoires in reptiles. Although the reptile is ectothermic, phylogenetic tree showed that reptilian TRPVs claded close to endotherms chicken, rather than ectotherms frog and fish.
Expression of TRPV4 mRNA was found to be ubiquitous in tissues/organs in the lizard. Cold and hibernation altered the expression profile, but in different ways. Cold-treatment of the lizard reduced the TRPV4 expression in tongue and muscle, while other tissues/organs remained unaffected. In contrast to cold-treatment, hibernation reduced TRPV4 expression in brain, tongue, heart, lung, and muscle, while the levels of the mRNA in the skin and liver remained nearly unchanged. It is generally assumed that cold is one of the inducers of hibernation. However, our results confirm that hibernation requires several factors/conditions in addition to cold, since expression profiles of TRPV4 differed between cold-treatment and hibernation.

Both ectotherms and endotherms may sense the environmental temperature through skin (Patapoutian et al., 2003; Egan et al., 2005). Brain is also important for sensing temperature, and it regulates animal behavior to adapt environmental change (Hammel et al., 1967; Nelson et al., 1984). Reptiles always sense temperature through skin and tongue. Accordingly, our observation that expression of TRPV4 in the skin remained unchanged during hibernation or cold-treatment also supports the notion that skin is probably one of the major tissues that continuously sense environmental temperature throughout the reptile life cycle, including the hibernation period. In mammals, TRPV4 contributes to the formation of an intracellular junctiondependent barrier in the skin, in addition to sensing of ambient temperatures (Sokabe et al., 2010; Sokabe and Tominaga, 2010). The skin barrier functions to avoid dehydration of the skin. If this is the case for reptiles, TRPV4 may also act to prevent skin from dehydration during hibernation, or at a stage of emergence from hibernation when environmental temperature (soil temperature) increases in early spring (Grenot et al., 2000). However, although amino acid sequence of the reptilian TRPV4 is quite similar to those of thermo-sensitive TRPV4 in other animals, physiological role of the reptilian TRPV4, such as thermo-sensitivity, is actually unknown at present. This point needs to be elucidated in the future.

\section{ACKNOWLEDGMENTS}

We thank Dr. A. Rahman in Iwate University for critical reading of the manuscript. We also thank Dr. M. Kuro-o at Hirosaki University for valuable suggestions, and K. Kogusuri for technical assistance. This study was supported, in part, by Grants-in-aid from the Ministry of Education, Science, Sports and Culture of Japan (nos.19916009 and 20918013 to K.N.).

\section{REFERENCES}

Chomczynski P, Sacchi N (1987) Single-step method of RNA isolation by acid guanidinium thiocyanate-phenol-chloroform extraction. Anal Biochem 162: 156-159

Damann N, Voets T, Nilius B (2008) TRPs in our senses. Curr Biol 18: R880-R889

Egan GF, Johnson J, Farrell M, McAllen R, Zamarripa F, McKinley MJ, et al. (2005) Cortical, thalamic, and hypothalamic responses to cooling and warming the skin in awake humans: a positron-emission tomography study. Proc Natl Acad Sci USA 102: 5262-5267

Everaerts W, Nilius B, Owsianik G (2010) The vallinoid transient receptor potential channel Trpv4: from structure to disease. Prog Biophys Mol Biol 103: 2-17

Gracheva EO, Ingolia NT, Kelly YM, Cordero-Morales JF, Hollopeter 
G, Chesler AT, et al. (2010) Molecular basis of infrared detection by snakes. Nature 464: 1006-1011

Grenot CJ, Garcin L, Dao J, Herold J, Fahys B, Tsere-Pages H (2000) How does the European common lizard, Lacerta vivipara, survive the cold of winter? Comp Biochem Physiol A Mol Integr Physiol 127: 71-80

Hammel HT, Caldwell FT Jr., Abrams RM (1967) Regulation of body temperature in the blue-tongued lizard. Science 156: 12601262

Iwabe N, Hara Y, Kumazawa Y, Shibamoto K, Saito Y, Miyata T, et al. (2005) Sister group relationship of turtles to the bird-crocodilian clade revealed by nuclear DNA-coded proteins. Mol Biol Evol 22: 810-813

Kraus C, Liehr T, Hulsken J, Behrens J, Birchmeier W, Grzeschik $\mathrm{KH}$, et al. (1994) Localization of the human beta-catenin gene (CTNNB1) to 3p21: a region implicated in tumor development. Genomics 23: 272-274

Liedtke W, Choe Y, Marti-Renom MA, Bell AM, Denis CS, Sali A, et al. (2000) Vanilloid receptor-related osmotically activated channel (VR-OAC), a candidate vertebrate osmoreceptor. Cell 103: 525-535

Michaelidis B, Loumbourdis NS, Kapaki E (2002) Analysis of monoamines, adenosine and GABA in tissues of the land snail Helix lucorum and lizard Agama stellio stellio during hibernation. $J$ Exp Biol 205: 1135-1143

Nelson DO, Heath JE, Prosser CL (1984) Evolution of Temperature Regulatory Mechanisms. Amer Zool 24: 791-807

Patapoutian A, Peier AM, Story GM, Viswanath V (2003) ThermoTRP channels and beyond: mechanisms of temperature sensation. Nat Rev Neurosci 4: 529-539

Phelps CB, Huang RJ, Lishko PV, Wang RR, Gaudet R (2008) Structural analyses of the ankyrin repeat domain of TRPV 6 and related TRPV ion channels. Biochemistry 47: 2476-2484

Rzhetsky A, Nei M (1992) A simple method for estimating and testing minimum-evolution trees. Mol Biol Evol 9: 945-967
Saito S, Fukuta N, Shingai R, Tominaga M (2011) Evolution of vertebrate transient receptor potential vanilloid 3 channels: Opposite temperature sensitivity between mammals and western clawed frogs. PLoS Genet 7: e1002041

Seebacher $F$ (1999) Behavioural postures and the rate of body temperature change in wild freshwater crocodiles, Crocodylus johnstoni. Physiol Biochem Zool 72: 57-63

Seebacher F, Murray SA (2007) Transient receptor potential ion channels control thermoregulatory behaviour in reptiles. PLOS ONE 2: e281

Sokabe T, Tominaga M (2010) The TRPV4 cation channel: A molecule linking skin temperature and barrier function. Commun Integr Biol 3: 619-621

Sokabe T, Fukumi-Tominaga T, Yonemura S, Mizuno A, Tominaga $M(2010)$ The TRPV4 channel contributes to intercellular junction formation in keratinocytes. J Biol Chem 285: 18749-18758

Tamura K, Dudley J, Nei M, Kumar S (2007) MEGA4: Molecular Evolutionary Genetics Analysis (MEGA) software version 4.0. Mol Biol Evol 24: 1596-1599

Thompson JD, Higgins DG, Gibson TJ (1994) CLUSTAL W: improving the sensitivity of progressive multiple sequence alignment through sequence weighting, position-specific gap penalties and weight matrix choice. Nucleic Acids Res 22: 4673-4680

Venkatachalam K, Montell C (2007) Trp Channels. Annu Rev Biochem 76: 387-417

Voets T, Talavera K, Owsianik G, Nilius B (2005) Sensing with TRP channels. Nat Chem Biol 1: 85-92

Vriens J, Owsianik G, Voets T, Droogmans G, Nilius B (2004) Invertebrate TRP proteins as functional models for mammalian channels. Pflugers Arch 449: 213-226

Xu GM, Arnaout MA (2002) WAC, a novel WW domain-containing adapter with a coiled-coil region, is colocalized with splicing factor SC35. Genomics 79: 87-94

(Received September 13, 2011 / Accepted October 5, 2011) 